\title{
The Potential Use of Smartphone and Social Networks in Public High Schools: A Survey of a Study Case in Palmas, Tocantins - Brazil
}

\author{
Eva Silva Daltio, José Antonio Aguiar Gama, George França, David Nadler Prata, Patrick Letouze and \\ Waldecy Rodrigues
}

\begin{abstract}
The use of mobile technologies in contemporary society increases every day, influencing social, political, economic and cultural relations. Paradoxically, relations in the educational context have been impacted to the practice in the classroom, because schools have to face a society living harmoniously with technologies and the challenge to integrate it into the curriculum and teaching practices. In particular, smartphones have a great potential as a medium to support teaching and learning, therefore, this paper discusses the relevance of the relationship between smartphones and social networks as technologies compatible with the pedagogical demands of the 21st century School, and its aim is to highlight the potential of these technologies to the production of knowledge in the processes of teaching and learning. The information in this study was extracted from public high schools at Palmas, capital city of Tocantins - Brazil, in which 212 students and 27 teachers participated. The results endorse the need to change from traditional teaching to a practice focused on curricular integration of Information and Communication Technologies - ICT, considering the intense relationship and the time of students and teachers with the virtual world. This relationship is intensified by the popularization and dissemination of mobile technologies and the importance attributed to social networks in the context of social relations.
\end{abstract}

Index Terms-Smartphone, social networks, learning, digital technologies, school.

\section{INTRODUCTION}

The advancement of science and technology in the last decades has defined a milestone in contemporary society, the so-called "knowledge society" defined by Castells [1]. Th is phenomenon consolidated the presence of a new time in communications. In this scenario, Information and Communication Technologies (ICT) assume a great importance to the global context, where knowledge generates and improves new technologies, contributing to the production of new knowledge in a continuous cyclic process.

In this sense, the United Nations Educational, Scientific and Cultural Organization (UNESCO) gives prominence to mobile technologies, characterized by the use of tablets, iPads, portable book devices, game consoles, and especially smartphones, defining mobile devices as:

...digital, easily portable, owned and controlled by an individual rather than an institution, with access to the internet and multimedia aspects, capable to facilitate a large

Manuscript received September 8,2018; revised November 12, 2018.

David Nadler Prata is with Universidade Federal do Tocantins (UFT) Brazil (e-mail:ddnprata@uft.edu.br). number of tasks, particularly those related to communication [2].

This scenario influences and contributes to the transformations in social relations evidenced by the use of the various media, mainly due to the internet. These technologies reinvent and are reinvented by every function, thing, or attribute; the innovations, adaptations and discoveries succeed, overlap, interconnect and complement each other in a linear, bidirectional or multidirectional sense, characterizing the flow spaces of Castells' society design [1].

Due to this techno-sociocultural panorama, it is possible to visualize and verify the power and influence of social networks in people's lives, as well as the ease of access to different social groups, due to the phenomenon of mobility and portability, characterized by the presence of mobile devices, notably the popularization of smartphones .

Associated with the increasing speed of in formation access, competitiveness for the production of smartphone applications intensifies, making it possible to access all types of services and interests of users. This ubiquitous characterization allows the formation of social networks, in which users can carry out any type of business interest, whether consumer or content producer.

It should be noted that young people are connected to the Internet and to social networks, producing, distributing and consuming a lot of information. This reality has generated increasing demands in relation to the number of users gradually avid for new electronic devices with capacity for the production and distribution of contents.

The popularization of the smartphones, associated with the facilities and attributes of ICT, has given a new identity to the youth of the 21st century, regardless of the social class to which it belongs. Just as ICT exerts pressure on the industrial, economic and social processes of production, also does educational policies to their respective didactic-pedagogical processes within Brazilian public schools.

Hence, this paper is presented in four sections. First the introduction, where will be visualized the theme and its evolution, in agreement with the smartphones, social networks and teaching and learning. In section two, the relationship between smartphone and social networks is approached in greater depth, based on many authors, such as [5], [12]-[21]. Statistical data are extracted from the Brazilian Institute of Geography and Statistics (IBGE), the National Telecommunications Agency (ANATEL), the Global System for Mobile Association (GSMA) and the United Nations Educational, Scientific and Cultural Organization (UNESCO). In section three, the data of a high 
school of Palmas is presented. The database is analyzed in relation to the provision of teachers to integrate the use of ICT in public education. Finally, in section four, the opinions and conclusions built during the survey are carried out.

\section{SMARTPHONES AND SOCIAL NETWORKS}

From the first telephone call that took place in April 1973 to the present, the cellular device went through a process of evolution that marked the his tory of teleco mmunications [3]. In 2007, with the launch of iPhone by Apple, s martphones have emerged and taken a leading position in the world [3].

The dynamics of this evolution from the cellular apparatus to the smartphones is present, both in its anatomical and functional structure, and in the fact that it becomes a ubiquitous and pervasive phenomenon, according to Hansmann [4]. The most part of its popularization is due to the convergence property of applications available for the most different types of users and services, as well as the refinement related to the size, weight and quality of images. These characteristics identify it as a kind of "handyman", in the view of Lemos [5].

Conceptually, the property of mobility can be understood as the possibility of using mobile devices connected during displacements [6]. In contrast, the portability is the faculty that fixed and mobile telephony users have been given to carry their lines to the operators that best suite them [7].

The estimation of the IBGE, Brazilian Institute of Geography and Statistics, Brazil has more than 207 million inhabitants. It is the Latin A merican country best placed in relation to the use of smartphones, with 234.6 million devices connected to the internet (2017). Of this total, $73 \%$ use the $4 \mathrm{G}$ technology, according to a report from the GSMA agency, responsible for GSM technology [8].

It is necessary to consider that the evolution of Internet access services in Brazil are boosting the connectivity indexes. According to the Digital Convergence agency, released in November 2017, 3G technology, surpassing the target for 2017, and already reached more than 5 thous and Brazilian municipalities. The $4 \mathrm{G}$ network is already present in more than 3,000 municipalities. There are more than 88.5 million accesses by August 2017. The 5G technology is scheduled for the market at 2019 and it promises to be far superior to its predecessor. Additionally, according to a survey released in November, 2017, by the National Telecommunications Agency (ANATEL), Brazil has more than 241 million lines in operation and a density of 116.96 cells per 100 inhabitants [7].

This context and the evolution in the provision of services to the user makes it increasingly possible to access information through mobile devices at anytime and anywhere. Despite the numerous applications for mobile devices, social networks have a central role, which in accordance to Telles [9, p.7] "are environments that focus on bringing people together... exposing their profile with data such as personal photos, texts, messages and videos, and interacting with other members, creating lists of friends and communities", and that attracts young people contributing to the improvement of their abilities using these resources.

Social Networks may provide a potential benefit to the composition of methodological actions that contributes to the quality of teaching and learning, especially the learning of young students. Consequently, it is no longer possible to consider the processes of teaching and learning alienated from the technological resources of contemporary society. There is no prospect of regression. On the contrary, there is an increasingly consistent world trend, a panorama, where the real and the virtual world meet, completed and interconnected.

Immersed in this universe of cutting-edge technologies, the smartphone has become an object of personal use of fundamental importance in people's lives, especially in the lives of young people who feel comfortable as part of this context. "In this new spatial logic there is a social pressure that demands the necessity of belonging, awakens in individuals a greater need for consumption of goods that identifies them with groups they want to contact." [10, p.8].

In this sense, this study aims to unders tand the relevance of social networks and smartphones in the teaching and learning processes in public high schools in Palmas, State of Tocantins, Brazil, allowing the expansion of knowledge production possibilities. In this crossroad, from Bonilla's point of view [11, p.70] "it is necessary to extrapolate the classroom, to participate in the daily life, to dare..." Then it is possible to contribute to the dynamics of the classroom by allowing and initiating the practice of knowledge production by students, rather than the traditional practice of informational consumption where "students and teachers close themselves between the four walls of the classroom, as in a vial, without communicating and establishing relations with the external context" [11, p. 69-70].

This distancing between contemporary technologies and pedagogical practices contrasts with the affinity and interest of young people for technologies and constitutes on of the greatest challenge for teachers nowadays, and according to Valente [12, p.56], “... the knowledge society requires that all people be able to learn continuously and become life long learners", and Medeiros [13, p.29] corroborates with it: "an important challenge to face is therefore the appropriation of the multiple ICT and the media languages as effective teaching and learning instruments". To do this, in addition to the resources themselves, are necessary measures to provide training by teachers for their use, when it is desired to bring about significant changes in the way of teaching and learning".

\section{DAT A AND ANALYSIS}

Our investigation starts by questioning the use of social networks by students and teachers of a public high school in Palmas, capital city of Tocantins. We verified that Whats App and Facebook are highly used in equivalent percentages, and that Instagram and Twitter have predominant access of students in relation to the percentage of teachers, Fig.1.

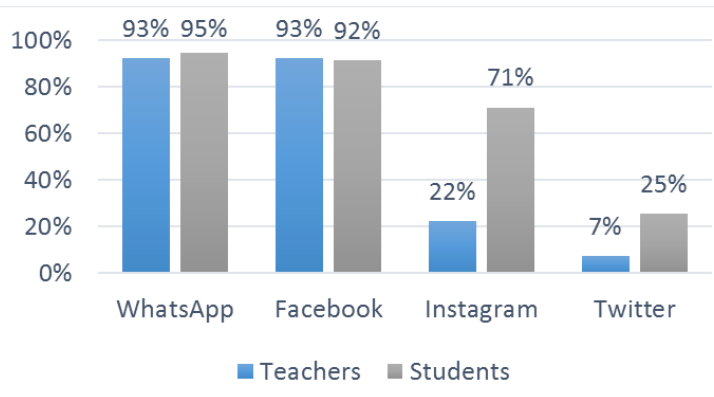

Fig. 1. The use of social networks. 


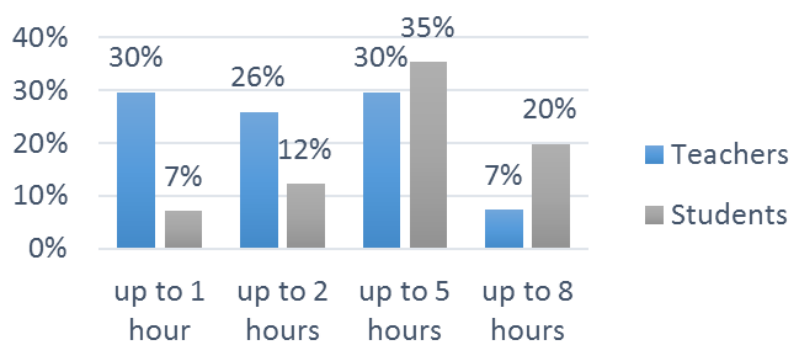

Fig. 2. Average time spent accessing social networks on a daily basis.

When teachers and students were asked about "on average, how much time per day do you spend accessing social networks?" the most part states that they are connected almost every day, Fig. 2. Still, we have that $30 \%$ of teachers and $35 \%$ of students use per day up to 5 hours. Up to 8 hours per day, there are $7 \%$ of teachers and $20 \%$ of students. It is clear with this result that social networks are part of their everyday life, interconnecting and entertaining them ${ }^{1}$.

Then we asked about the "purpose of the use of social networks", we found out that $74 \%$ of teachers and $85 \%$ of students said they use social networks for leisure and entertainment, Fig. 3. Additionally, 93\% of teachers and $49 \%$ of students use for communication; $67 \%$ of teachers and $31 \%$ of students use for work; and finally, $56 \%$ of teachers and $86 \%$ of students use social networks for educational purposes. Oddly enough, when questioned if "they did any pedagogical activity at school using socialnetworks", $52 \%$ of teachers and $53 \%$ of students said they have not done, Fig. 4.

When questioned about "the belief that social networks definitely influence people's opinions," $74 \%$ of teachers and $59 \%$ of students think so; $26 \%$ and $34 \%$ respectively answered that "in part", Fig. 4. This paradigm of belief in social networks is based on the fact that today's society is networked, which in turn dictates the rules, change habits, customs, incorporate values and influences life itself. We also asked, "If it is possible to learn educational content with social networks?", the results are shown in Fig. 6. We verified that $85 \%$ of teachers and $89 \%$ of students said yes. This result shows that many students and teachers have a predisposition to learn and teach using social networks.

If we consider that $74 \%$ of teachers and $59 \%$ believe that social networks can influence people's opinions, then it is an opportunity to be explored for pedagogical purposes and for socialization of experiences among teachers and peers, or the students of this generation are articu lated in spaces created by social networks, as well as teachers.

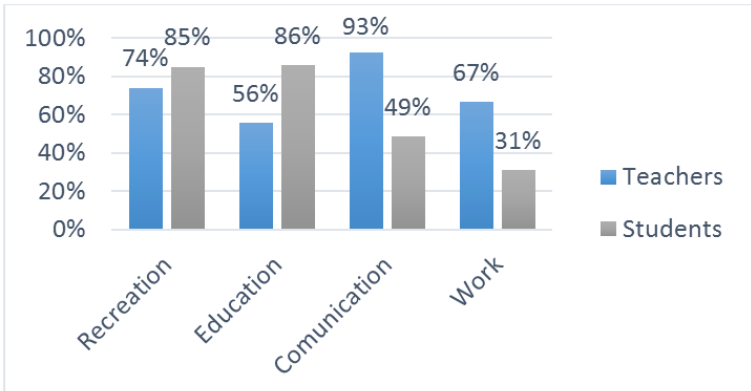

Fig. 3. Purpose of using social networks.

\footnotetext{
${ }^{1} 7 \%$ of the teachers and $26 \%$ of the students have not been able to respond.
}

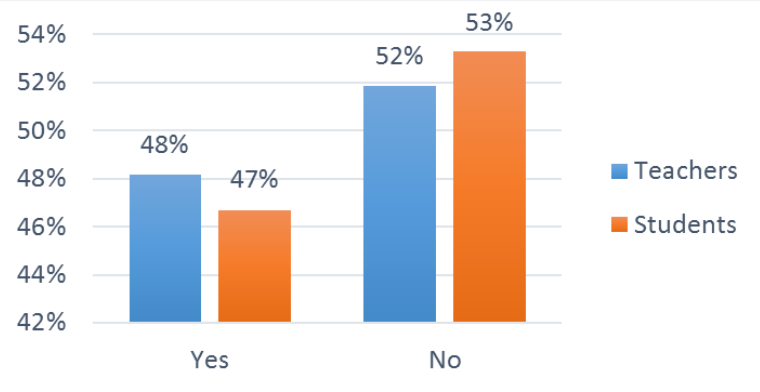

Fig. 4. If there are classroom learning activities using social networks.

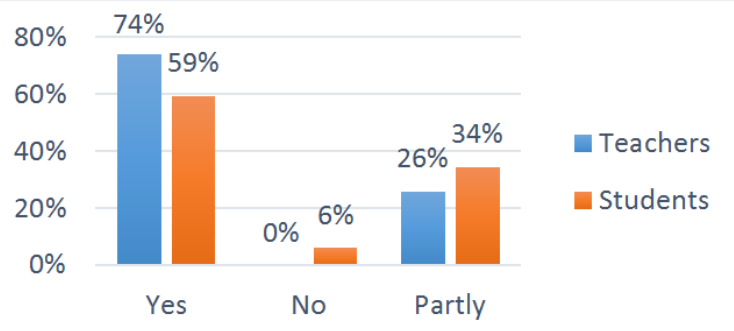

Fig. 5. Belief in the influence of social networks on people's opinions.

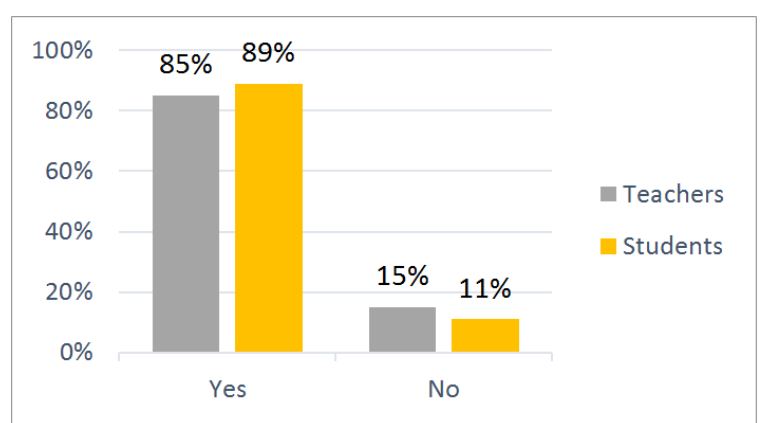

Fig. 6. It is possible to learn educational content using social networks.

In addition to the statistical data, we have noticed that many teachers are concerned and doing something to be acquainted with the virtual universe. Most still do not use social networks as a tool to carry out activities with students, even believing in the potentiality of these tools. However, it is understood as an opportunity to enrich pedagogical work, with not only research and educational games, but also to share ideas, develop projects and disseminate experiences within the school.

\section{GENERAL CONSIDERATIONS}

The approach of this work had the purpose to evaluate the potential context of didactic-pedagogical use of smartphones and social networks in the context of a public high school in Palmas. Nonetheless, it may be applied to public high schools in the entirety of the State of Tocantins, or even the rest of Brazil. The data indicate that to invest in the training of teachers for the pedagogical use of social networks with smartphones has potentially broad acceptance by both teachers and students. In this sense, it is wise to consider:

1. The need for improving the proficiency of Brazilian students in the rankings published by international organizations, such as PISA (2015), where Brazil ranked among the last 70 countries surveyed.

2. The need to integrate school practices with ICT.

3. That technologies are means and ends, according to specific intentionality. 
4. The easiness to access social networks and other productivity applications.

5. The potential of pedagogical activities with the use of smartphones as sociated with social networks.

6. That in Brazil, according to data released by ANATEL, the density of mobile lines per inhabitant is $116.96 \%$, and in Tocantins the density is $115.23 \%$.

7. That ICT is present in all fields of human knowledge and it has shown no downward trend. On the contrary, researches in emerging technologies, such as the areas of artificial intelligence, connectivity, augmented reality, among others, have intensified and, more and more, researchers are committed to developing new products and contents with new functions and skills for the service and adaptation of different spaces and situations in the life and activities of people.

Therefore, there is no doubt about the potential benefit of the use of smartphones and social networks in the service of teaching and learning, because of their broad acceptance, Fig. 1, and extensive use Fig.2, i.e., students and teachers are already using Social Networks with smartphones, then how can we increase their use in education? That is the doubt, to make the $m$ increase the use for education in comparison to other uses, Fig.3.

The challenge seems to be directly related to the need for teacher training, in order to develop pedagogical activities in harmony with this new scenario marked by the mastery of technologies. However, the inferences made from the data analyzed show that it is necessary to investigate this topic more thoroughly, since the experiences of teachers regarding the use of smartphones and social networks in their pedagogical practices are slowly evolving. This is raised by the combined analysis of Fig. 3 and Fig.4, where we have that $56 \%$ of teachers and $86 \%$ of students use social networks for educational purposes, but when asked about its use at school, $52 \%$ of teachers and $53 \%$ of students said they have not done. This contradiction proves that further studies are required. It also shows that the majority of teachers and almost all students are ready and using this new reality for learning.

In this context, we have to consider also that in the School Rules of the State Teaching Network of Tocantins, article 41 [14]: "It is forbidden to the student, in the school premises: II - to use a cellular device, smartphones, tablets cameras, headphones and any other sound system in the classrooms, except when contemplated in school planning". That is, on one hand, the institutional organization itself imposes restrictions, legalizing the lack of skills to creatively and productively deal with technologies. On the other hand, there is a demand for professionals trained in the field of emerging technologies in education.

The combination of the School Rules of the State Teaching Network of Tocantins, article 41, with the results of this study shows that if we want to use Social Networks with smartphones to improve the teaching and learning process, we have to promote teachers' training in these technologies and to stimulate their inclusion in schoolplanning.

\section{REFERENCES}

[1] C. Manuel, "The information age: economy, society and culture," The Rise of Network Society, Oxford. Blackwell, 1996.

[2] UNESCO Policy Guidelines for Mobile Learning. 2013, France. Trad. UNESCO, Brasil. [Online]. Available http://unesdoc.unesco.org/images/002 1/002196/219641E.pdf
[3] Telefone celular completa 40 anos de vida. [Online]. Available http://www.beecreative.com.br/telefone-celular-completa-40-anos-devida

[4] H. Uwe, Pervasive Computing: The Mobile Word Springer, 2003.

[5] Lemos, André. Cibercultura e Mobilidade: a Era da Conexão. [Online]. Available:

https://www.razonypalabra.org.mx/anteriores/n41/alemos.html

[6] J. A. Mário, "Mobilidade e acessibilidade: conceitos e novas práticas," Revista Indústria e Ambiente, 2009.

[7] Anatel. Agência Nacional de Telecomunicações. [Online]. Available: http://www.anatel.gov.br/dados/component/content/article?id=28

[8] IBGE. [Online]. Available: ftp://ftp.ibge.gov.br/Estimativas_de_Populacao/Estimativas_2017/esti mativa_TCU_2017.pdf

[9] TELLES, André. A revolução das mídias sociais. Cases, conceitos, dicas e ferramentas. M. Books do Brasil Editora Ltda. - São Paulo 2010.

[10] E. Daltio, G. França, and D. Prata, Reflexões sobre o uso dos smartphones com fins educacionais nas escolas. [Online]. Available: http://revista.srvroot.com/linkscienceplace/index.php/linkscienceplace /article/view/328

[11] B. M. Helena, Escola Aprendente: para além da sociedade da informação, Cibercultura e Educação. Quartet. Rio de Janeiro-RJ, 2005.

[12] J. A. Valente, Aprendizagem e mobilidade: os dispositivos móveis criam novas formas de aprender? vol. 1,2014

[13] M. L. Lopes, Educação a Distância e formação de Professores: Relatos e experiências. Coordenação Central de Educação a Distância PUC Rio (Organização), Rio de Janeiro. Ed. PUC - Rio, 2007.

[14] Regimento Escolar da Rede Estadual do Tocantins, SEDUC/TO. Disponível. [Online]. Available: https://central3.to.gov.br/arquivo/371242/

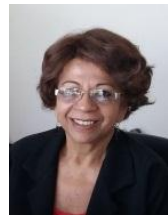

Eva Silva Dal tio is a master's student in Computat ional systems modeling with emphasis in education in Information and Communication Technologies, Federal University of Tocantins - UFT. She has studied masters in integrated Technologies and the Knowledge Society by UNED - Spain (2009). Specialist in Educational Administration (ASOEC - RJ), (1993) and in Technologies in Education (PUC-Rio) (2008). Graduated in Geography by the University Center of Brasília - UNICEUB (1986).

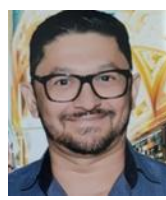

José Antonio Aguiar Gamawas graduated in pedagogy (2000) and history (2001) by the State University of Piauí, Specialist in Psychopedagogy by Facinter (2004), master in digital technologies and Knowledge Society - National University of Distance Education (2010). Master's student in Computational Modeling of System by Federal University of Tocantins (2017) and General Director of São José State College in the municipality of Palmas (2015 - 2017). Has experience in teaching elementary, middle and university education.

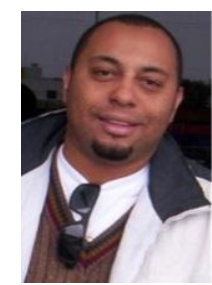

George França is a pprofessor at the Federal University of Tocantins UFT in the course of Pedagogy and in the Program of Postgraduate in Computational Systems Modeling. Doctor of Education from Pontifical Catholic University of São Paulo. Graduated in Philosophy at the Federal University of Santa Catarina - UFSC. Master in Production Engineering and Systems: Media and Knowledge from UFSC. He develops

teaching, research and extension activities in the field of educational technology, distance education and philosophy of education. He is currently Pro-Chancellor of Extension and Culture of the Federal University of Tocantins UFT.

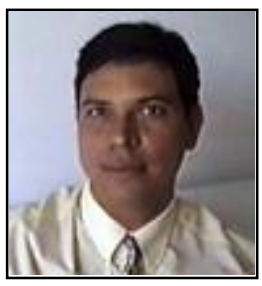

David Nadler Prata began his professional activities in the army in 1989, where he designed and implemented an information system for the National Information Service (SNI). He was part of the implementation team of the first Data Processing Center of the State of Tocantins. He developed the State Asset system in Natural / Adabas, MVS-IBM, and later assumed responsibility for the State Budget, Financial and Accounting systems. Elaborated the PDI (Computer Master Plan) of the State for a period of eight years. 
He performed downsinzing from mainframe financial systems to HP-UX / Risc with Brasilia's SERPRO, deployed Infoseg in Tocantins with American FBI technology. He took his master's degree in computer science in Campina Grande-PB. In 2000, he went to the US where he received his CCNA certificate from Cisco. He worked as a CNPq researcher for the FIACI Project (ProTeM-CC-CNPq) - UFPE / UFAL, in Maceió-AL

Doctor Prata published and presented papers as the first author on CSCL and evaluation of distance learning in Finland, Stanford, Kuala Lumpur, Paris, London, China, Brasília, Rio de Janeiro, São Luiz and São Paulo. He served as an IEEE reviewer for Transactions on Education. At UFT, he is responsible for the elaboration of the project of Interdisciplinary Professional Master in Computational Modeling of Systems, authorized by capes on 04/03/2012, which he is currently coordinating. He is a Researcher of the Biodiversity Research Program (PPBio) of the Tocantins Nucleus, Coordinator of Universal Project of CNPq, Edital 2014, Producer of UFT; Permanent Professor of the Post graduate Program in Teaching in Science and Health, IEEE Transactions on Knowledge and Data Engineering, Permanent Professor of the Postgraduate Program in Public Policy Management.

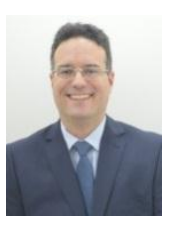

Patrick Letouze Moreira has a bachelor degree in Control and Automation Engineering (Universidade Federal de Santa Catarina, class of 98.2), and his final project was about project management of photonic telecommunications systems. Also, he has a Master Science degree in Electrical Engineering in the field of telecommunications, and his dissertation was about image processing with JPEG (Universidade de Brasília, February, 2013). His Doctor in Science degree was also in Electrical Engineering, and his thesis was about Health Management Information Systems.

$\mathrm{He}$ is adjunct Professor at Universidade Federal do Tocantins-UFT. He operates in the programs: Masters in Computational Modeling of Systems (Vice-coordinator); Masters in Science and Health Education (coordinator); Undergraduate in Computer Science and a Degree In informatics. Moreover, he act $s$ as a lect urer for the opening of scientific events (keynote speaker) and as Academic coordinator of Scientific Conferences (Conference Chair) since 2011, especially by the IEDRC (International Economics and Development Research Center) where he is a "fellow" member.

Dr. Letouze has several interdisciplinary publications, highlighting his interest in interdisciplinary projects management, research methodology (in particular systematic reviews), development of information management systems, health informatics, educational systems and technologies, and information modeling. He Developed the RGM which is an information management system for the support of medicine based on evidence with application to in organ transplant management.

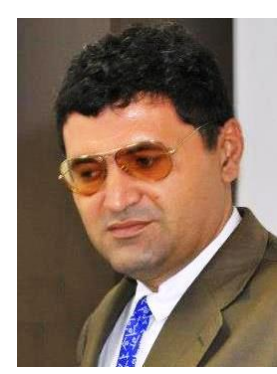

Waldecy Rodrigues is graduated in Economics from the Pontifical Catholic University of Goiás (PUC-GO) with a Master's degree in Economics from the University of Brasília (UnB), Ph.D. in Comparative Development Studies in the Americas (UnB) and Post-Doctorate in Economics (UnB).

$\mathrm{He}$ is currently an Associate Professor of the Post graduate Program in Regional Development at the Federal University of Tocantins. He was Dean of Research and Graduate Studies (2012-2016) and Adviser of the Sebrae Tocantins (2014-2017). He is currently an Editor at EDUFT. He follows the research lines of Economy of the Environment, with a specific focus on the Sociobiodiversity Productive Chains; Evaluation of Public Policies ; Territorial Development and Substantive Economy and Local Productive Arrangements, with special attent ion to the conceptual and epistemological development of Community-Based Productive Arrangements.

Dr. Rodrigues has experience in the area of Economics, with emphasis on Interfaces between Economy and Environment, Regional and Urban Development and Design and Evaluation of Public Policies. He is a member of advisory committee at Development agency (Agência de Fomento) as the Coordinator of Improvement of Higher Education Personnel. 